\title{
Ethnobotany Study of Medicinal Plants Used in the Treatment of Respiratory Diseases in the Middle Region of Oum Rbai
}

\author{
Ben Akka Fatiha ${ }^{1}$, Benkhnigue Ouafae ${ }^{1}$, Salhi Souad ${ }^{1}$, El Hilah Fatima ${ }^{1}$, Dahmani \\ Jamila $^{2}$, Douira Allal ${ }^{2} \&$ Zidane Lahcen $^{1}$
}

${ }^{1}$ Department of Biology, UFR: Mycology, Biodiversity and Natural Resources Laboratory, Kenitra Faculty of Science, Morocco

${ }^{2}$ Department of Biology, Botanical, Biotechnology and Plant Protection Laboratory, Kenitra Faculty of Science, Morocco

\begin{abstract}
The ethnobotanical study carried out in the region of Oum Rbia (Morocco) made it possible to identify the medicinal plants used by the local population and to collect the maximum information on this use.

A survey of 1360 people from the region's population noted that 170 people use medicinal plants against respiratory diseases. Women accounted for $55.3 \%$ of the workforce versus $44.7 \%$ for men; Married people $70 \%$ against $28 \%$ for singles. The illiteracy rate is high $(34.1 \%)$.
\end{abstract}

The leaves are the most widely used part of the plant. Infusion and decoction are the most commonly used methods for preparing traditional remedies.

The most widely used species in the treatment of respiratory diseases are: Origanun glandulosum, Eucalyptus globulus, Nigella sativa, Mentha pulegium, Lavandula stoechas, Zingiber officinale, Ammodaucus leucotrichus, Ficus carica. In addition, some species have toxicity either because of the ignorance of the necessary dose or because the people treated are affected by other diseases.

Thus, the survey made it possible to inventory 66 medicinal species which are divided into 36 plant families; Lamiaceae (21.2\%), Myrtaceae (10.6\%), Apiaceae (8.8\%), Amaryllydaceae (7.7\%) and Zingiberaceae $(7.1 \%)$.

These results resulted in a catalog of medicinal plants used in the study area to treat respiratory diseases. It is a local know-how that must be considered as a heritage to be preserved and developed.

Keywords-Oum Rbia, Ethnobotany survey, respiratory diseases and medicinal plant.

\section{INTRODUCTION}

The respiratory system (nasal passages, bronchi and lungs) can be the subject of several diseases: acute infections such as pneumonia and bronchitis, or chronic conditions such as asthma and COPD. Thus, respiratory diseases, regardless of the age of the patients, represent approximately 5.5 million medical consultations per year (Ministry of Public Health, 2001). In the majority of cases $(85 \%)$, these patients have acute respiratory diseases, mainly angina or acute bronchitis. The remaining cases $(15 \%)$, have a chronic respiratory disease or a suspicion of pulmonary tuberculosis (Ministry of Public Health, 2001). Among chronic respiratory diseases, asthma occupies the first place and pulmonary tuberculosis accounts for only 4 to $5 \%$ of cases (Ministry of Public Health, 2001).

The World Health Organization estimates that traditional medicine covers the primary health care needs of $80 \%$ of the population in developing countries (Vines, 2004). Plants still play a very important role in the medical traditions and life of the inhabitants of the Maghreb, but the rules of their use sometimes lack rigor and do not take into account the new demands of modern therapy (Bellakhdar, 2006).

Morocco, whose geographical location has a flora rich in diversity, has about 4200 species of which only a hundred are currently exploited according to El Meskaoui (2008). In order to preserve the natural heritage of the Middle Oum Rbai region, we carried out an ethnobotanical study collecting the knowledge, attitudes and practices of the local population concerning all the plants used in the Treatment of respiratory diseases.

\section{MATERIAL AND METHOD}

1. The study area:

Oum Rabia means the provinces of Khouribga, Fkih Ben Saleh and Kasbat Tadla. It is linked to the Beni MellalKhénifra region following the territorial division of 2015 (Fig. 1).

The Beni Mellal-Khénifra region is limited to the west by the regions of Casablanca Settat and Marrakech-Safi, to the south by the Draa Tafilalet region, to the east by the 


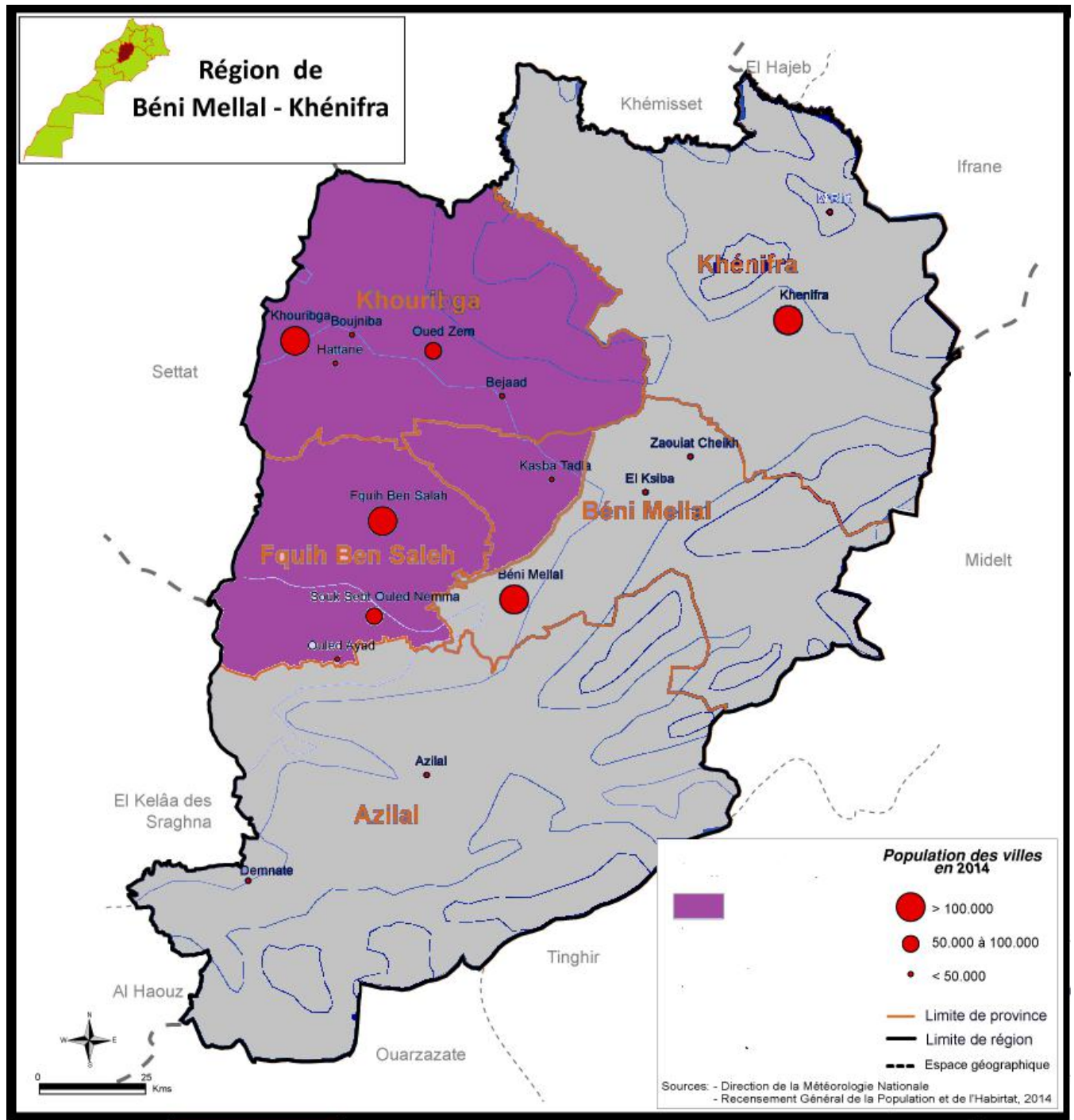

Fig.1: Map of the study area (General Monograph of the Beni Mellal-Khénifra Region, 2015)

\section{The methodology:}

An ethnobotanical survey was conducted in the Oum Rbia region between 2010 and 2015 and was based on stratified random sampling; A pre-established questionnaire based on information on the profile of the informant (Age, intellectual level, family situation ...) and on the other hand on the use of plants in traditional medicine (vernacular name of the plant, part used, dose used, method of preparation, disease treated, etc.). Plants are collected in the wild or obtained in traditional healers. The local name of the plant is given by the interviewees or by the traditional healers and the scientific name is determined in the laboratory. Determination of species was carried out thanks to the New flora of Algeria and the southern desert regions Quézel \& Santana (1962, 1963), volumes I and II; The Practical Flora of Morocco Fennane et al. (1999, 2007), Volume 1 and 2; Catalog of vascular plants in Northern Morocco, including identification keys, by Valdés et al (2002), volumes I and II; And the Vascular Flora of Morocco: inventory and chorology Fennane and Ibn Tattou (2005). Books such as: Medicinal plants of Morocco Sijelmassi (1993); The traditional Moroccan pharmacopoeia Bellakhdar (1997); And Moroccan medicinal and aromatic plants Hmamouchi (2001) have also been used for the recognition of medicinal plants.

\section{RESULTS}

The survey of 1360 people in the study area identified 170 people who use herbal medicines against respiratory diseases.

\section{$>$ The use of medicinal plants according to the survey:}

The calculations of the following proportions are made on the basis of the number of people who use medicinal plants against the ailments of 170 people. 
1) The informant by sex: The analysis of Figure 2 shows that women predominate in the use of medicinal plants in herbal medicine for respiratory diseases with $55 \%$ compared with $45 \%$ for men.

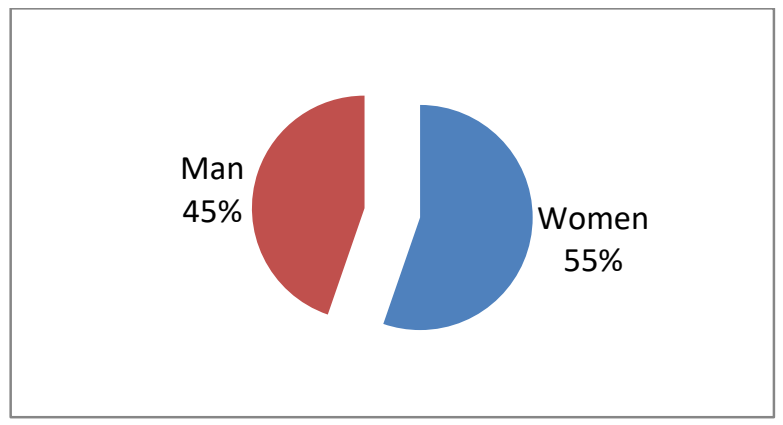

Fig.2: Use of Medicinal Plants by Sex in the Oum Rbai Region

2) The informant according to age: Analysis of the results obtained shows that $54 \%$ of the respondents belong to the age group] 30-50], $21 \%$ are over 50 years old, $18 \%$ are part of the age group] 20-30] and $7 \%$ are aged less than 20 years (Figure 3 ).

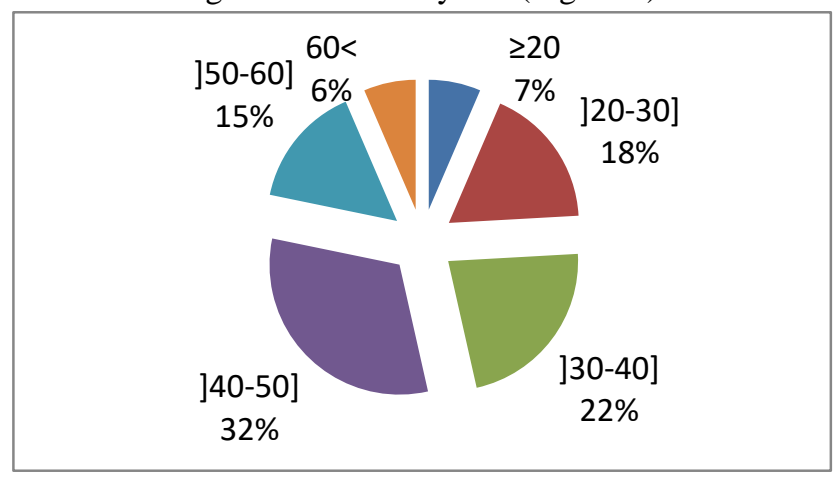

Fig.3: Use of Medicinal Plants by Age in the Oum Rbai Region

3) The informant according to the intellectual level: the results show that the illiterate persons represent $34 \%$ of the workforce, followed by secondary education with $27 \%$, primary school with $17 \%$, while the college level has $12 \%$ And academics $10 \%$.

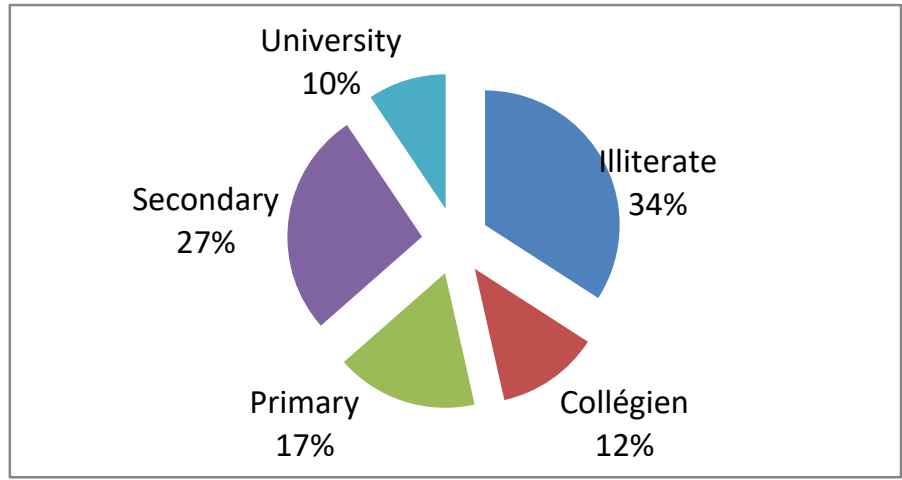

Fig.4: Use of Medicinal Plants by Study Level in the Oum Rbai Region

4) Profile of the informant according to the family situation: married people predominate with $70 \%$, against married couples who represent $28 \%$ and widowers $2 \%$ (Figure 4).

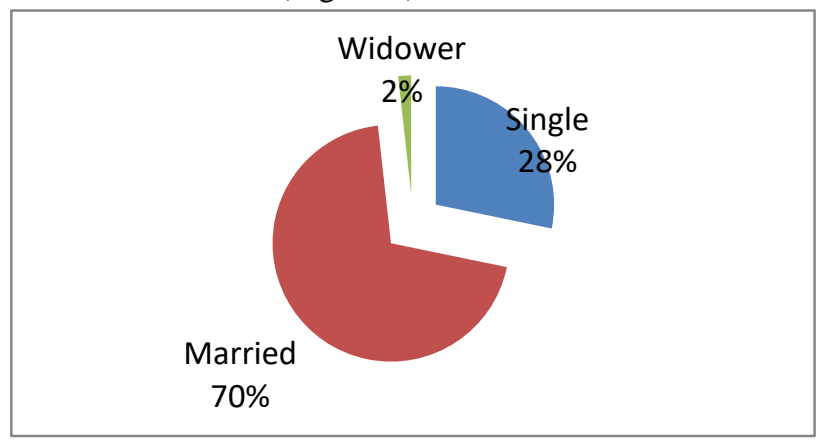

Fig.5: Use of Medicinal Plants by Family Status in the Oum Rbai Region

The use of medicinal plants according to the part used: Phytotherapy for the treatment of respiratory disorders is based first on the leaves (70 citations), then on the seed (34 citations), and finally on the rhizome and the whole plant with 18 citations for each of the two categories. For other parts of the plant, the number of citations is much lower (Figure 6).

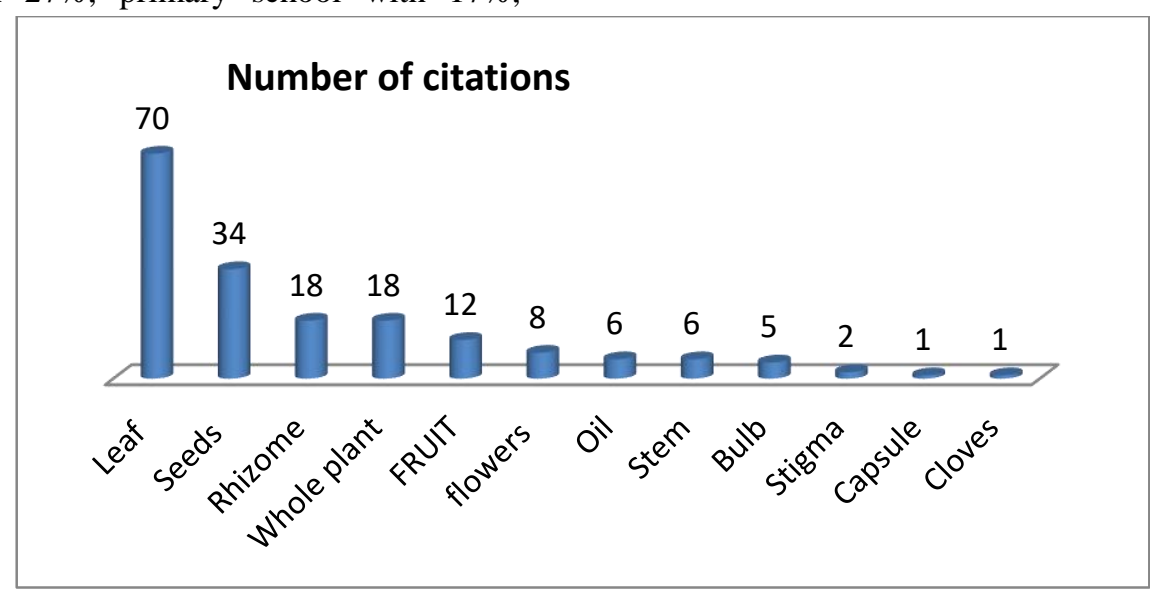

Fig.6: Plant parts used in herbal medicine in the Oum Rbai Region 
$>$ The Flora analysis: The floristic analysis shows that Origanum glandulosum is the most used species against respiratory diseases in the region of Oum Rbai followed by Eucalyptus globulus, Nigella sativa, Mentha pulegium, Lavandula stoechas, Zingiber officinale, Ammodaucus leucotrinarum and Ficus carica (figure7).

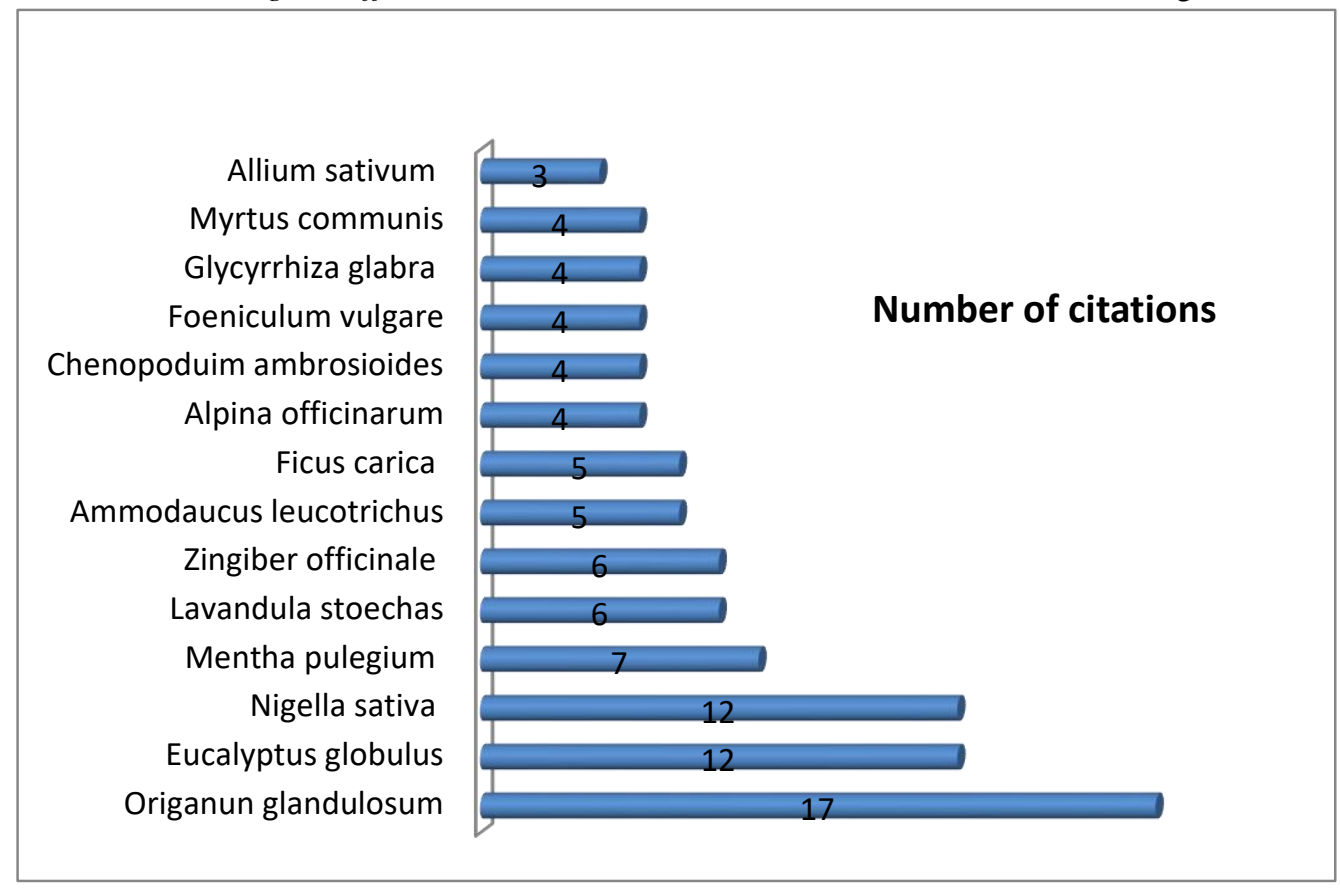

Fig.7: Medicinal plants most commonly used to treat respiratory diseases in the Oum Rbai region

The analysis of the results also shows that the Lamiaceae family is dominant with $21.2 \%$ of the resected species, Myrtaceae in second class with $10.6 \%$, Apiaceae with $8.8 \%$, Amaryllidaceae and Zingiberaceae with $7.1 \%$ each.

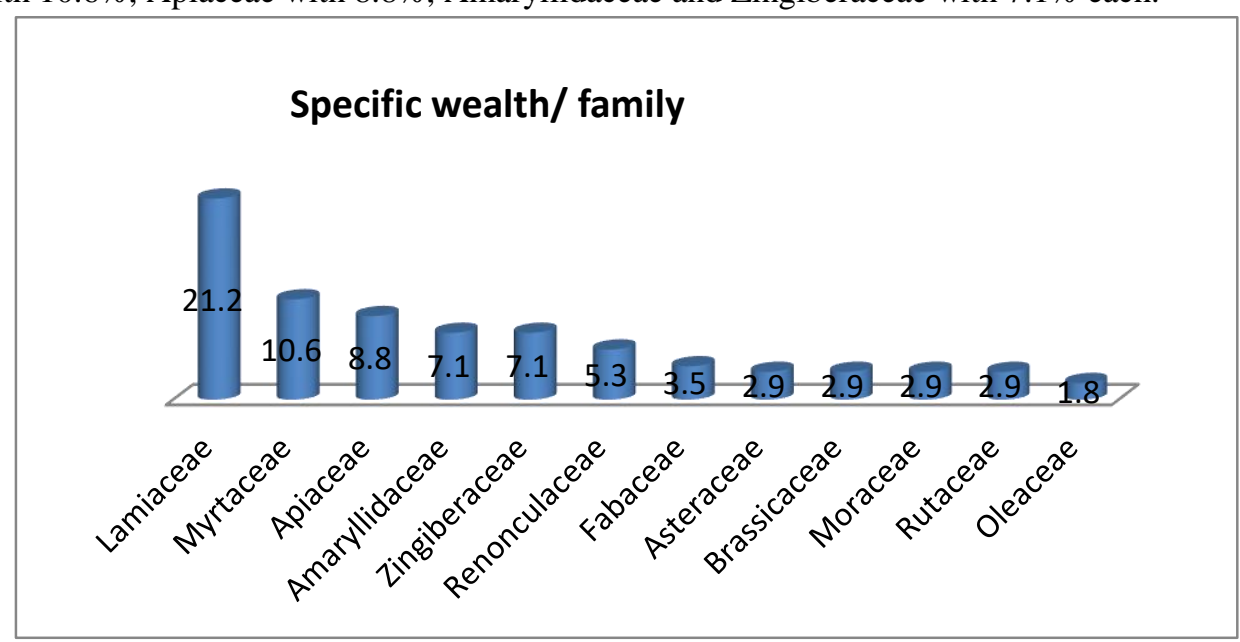

Fig.8: Specific Wealth of Families Represented to Treat Respiratory Diseases in the Oum Rbai Region

$>$ Respiratory diseases most frequently treated by plants: According to the results obtained, respiratory diseases most frequently treated by medicinal plants in the region of Oum Rbia are: influenza first with 47 citations, cooling with 44 citations, 39 citations concern respiratory diseases in general Because the inquiry does not specify the exact disease, but it uses the plant for all that concerns the respiratory apparatus, the cough (19 citations). 


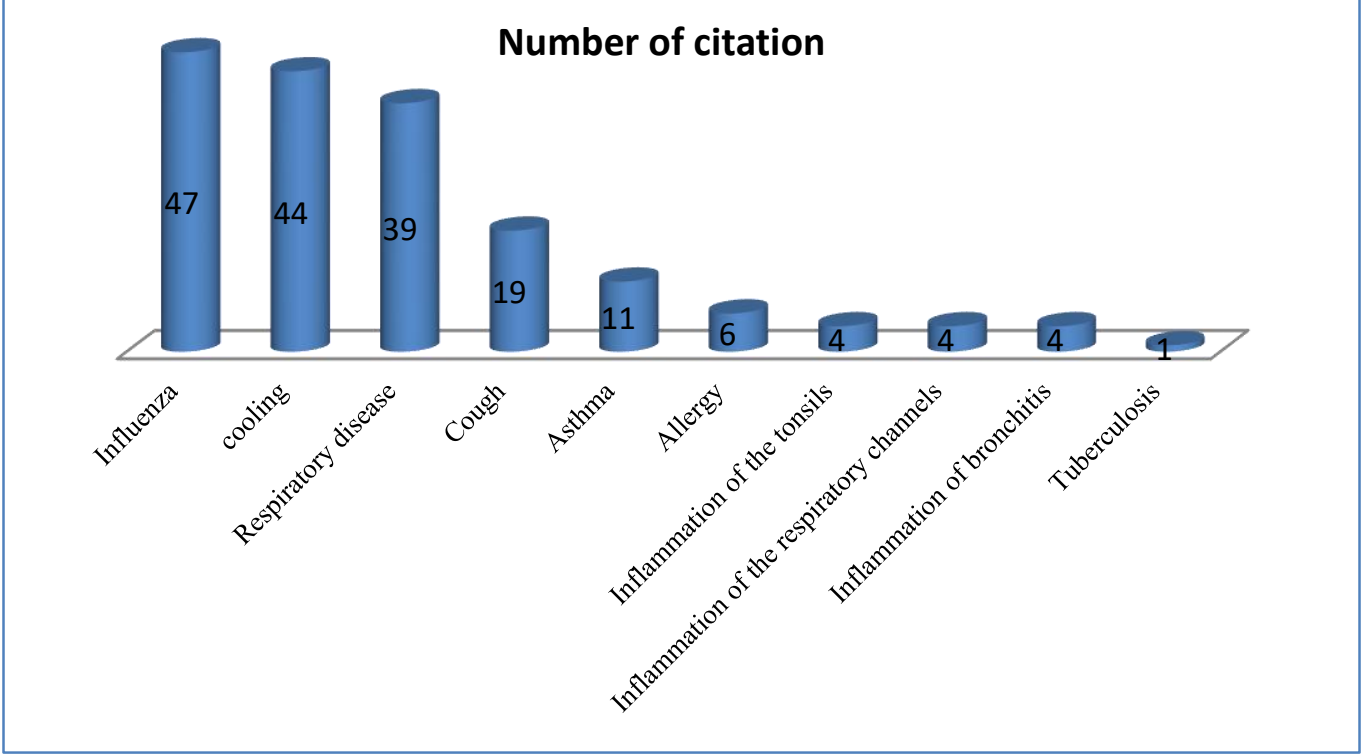

Fig.9: Respiratory diseases treated by plants in the Oum Rbai region

\section{DISCUSSION}

Analysis of the results obtained from 170 people using medicinal plants against respiratory diseases shows that women predominate for the use of medicinal plants with $55 \%$ against $45 \%$ for men. These results are consistent with those obtained by Hmamouchi (1999), Mehdioui (2008) and El Hilah (2015). 54\% of respondents belong to the age group] 30-50], $21 \%$ are older than 50 years, $18 \%$ are in the age group] 20-30] and 7\% are less than 20 years. This can be explained by the company's return to the use of traditional herbal medicine with a good transmission of the popular knowledge of the elderly towards the young (Hseini, 2008). Illiterates represent $34 \%$ of the workforce, followed by secondary schooling with $27 \%$, primary education $17 \%$, college $12 \%$ and university $10 \%$. A renewed interest in medicinal plants is noticed; People are beginning to become aware of the side effects of pharmaceutical treatments based on chemical molecules. The married population predominates with $70 \%$, against the singles who represent $28 \%$ and the widowed $2 \%$. These results are related to the responsibility of brides towards the needs of the family. This is consistent with the results obtained by other studies at the national level (Hseini, 2008, Benkhnigue, 2010, El Hilah, 2015 ...). Phytotherapy for the treatment of respiratory diseases relies primarily on the leaves, seed, rhizome and whole plant, for the other parts of the plant the number of citations is much lower.

Plant analysis shows that Origanum glandulosum is the most widely used species against respiratory diseases in the Oum Rbai region followed by Eucalyptus globulus, Nigella sativa, Mentha pulegium, Lavandula stoechas, Zingiber officinale, Ammodaucus leucotrinarum and
Ficus carica. The most common families are Lamiaceae, Myrtaceae, Apiaceae, Amaryllidaceae and Zingiberaceae. Lamiaceae also rank first in the study carried out in the Central Plateau of Morocco by El Hilah in 2016.

The respiratory diseases most frequently treated by medicinal plants in the region of Oum Rbia are flu, cooling, coughing. As for asthma, allergy and more serious lung diseases, the population uses less herbal medicine.

\section{CONCLUSION}

Surveys of 1360 people in the region have identified 170 people who use herbal medicines against respiratory diseases. The diseases most commonly used by herbal medicine are influenza, chills and coughs; People have less recourse to this mode of medication when conditions are more serious, such as asthma and tuberculosis. Thus, the survey made it possible to inventory 66 medicinal species which are divided into 36 plant families. . Women are predominant with $55.3 \%$ against $44.7 \%$ for men. Traditional medicine is more practiced by married people with $70 \%$ against $28 \%$ for singles. The illiteracy rate is high at $34.1 \%$. As for the plant, the leaves are the most used part. Infusion and decoction are the means of preparing the most used remedies. The species most commonly used in the treatment of respiratory diseases are: Origanun glandulosum, Eucalyptus globulus, Nigella sativa, Mentha pulegium, Lavandula stoechas, Zingiber officinale, Ammodaucus leucotrichus, Ficus carica. In addition, some species have toxicity either because of the ignorance of the necessary dose or because some people have other diseases. The results show a relative importance of the following families: Lamiaceae (21.2\%), 
Myrtaceae (10.6\%), Apiaceae (8.8\%), Amaryllydaceae $(7.7 \%)$ and Zingiberaceae $(7.1 \%)$. These results resulted in a catalog of medicinal plants used in the region to treat respiratory diseases. The catalog of 66 species testifies to a local know-how of great value, it is a heritage that must be preserved and managed in the sustainability.

Table.1: List of medicinal plants used in the treatment of respiratory diseases in the Middle Oum Rbia region

\begin{tabular}{|c|c|c|c|c|c|c|}
\hline Family & \begin{tabular}{|l} 
Vernacular \\
name
\end{tabular} & Scientific name & $\begin{array}{l}\text { Used } \\
\text { part }\end{array}$ & Preparation & $\begin{array}{l}\text { Administration } \\
\text { mode }\end{array}$ & Disease \\
\hline \multirow{6}{*}{ Amaryllidaceae } & Thoum & Allium sativum & Bulb & Decoction & Oral & $\begin{array}{l}\text { Respiratory, } \\
\text { cooling }\end{array}$ \\
\hline & Lamkhenza & $\begin{array}{l}\text { Chenopoduim } \\
\text { ambrosioides }\end{array}$ & Leaf & $\begin{array}{l}\text { Infusion, } \\
\text { Juice }\end{array}$ & $\begin{array}{l}\text { Oral, } \\
\text { fumigation, } \\
\text { massage }\end{array}$ & $\begin{array}{l}\text { Influenza, } \\
\text { tonsillitis, } \\
\text { respiratory }\end{array}$ \\
\hline & Selk & \begin{tabular}{|l|} 
Beta \\
vulgaris/serpetual \\
spinach
\end{tabular} & $\begin{array}{l}\text { Leaf, } \\
\text { whole } \\
\text { plant }\end{array}$ & Decoction & Oral & Respiratory \\
\hline & Sabra & Agave americana & Leaf & Decoction & Oral & Asthma \\
\hline & Pinard/sabanikh & Spinacia olearea & Leaf & Decoction & Oral & Respiratory \\
\hline & Basla hamra & Allium сера & Seed & Powder & Oral & Allergy \\
\hline \multirow{7}{*}{ Apiaceae } & Krafess & Apium graveolens & Leaf, oil & Infusion & Oral & $\begin{array}{l}\text { Calming } \\
\text { bronchitis }\end{array}$ \\
\hline & Nafeaa/basbass & $\begin{array}{l}\text { Foeniculum } \\
\text { vulgare }\end{array}$ & Seed, oil & $\begin{array}{l}\text { Decoction, } \\
\text { powder }\end{array}$ & Oral, massage & $\begin{array}{l}\text { Influenza in } \\
\text { babies and } \\
\text { allergy }\end{array}$ \\
\hline & Camoun souffi & $\begin{array}{l}\text { Ammodaucus } \\
\text { leucotrichus }\end{array}$ & Seed & Infusion & Oral & $\begin{array}{l}\text { Influenza, } \\
\text { cough }\end{array}$ \\
\hline & Kazbour lbir & $\begin{array}{l}\text { Coriandrum } \\
\text { sativum }\end{array}$ & $\begin{array}{l}\text { Whole } \\
\text { plant, } \\
\text { seed }\end{array}$ & Infusion & Oral, Rinsing & $\begin{array}{l}\text { Inflammation } \\
\text { of respiratory } \\
\text { ducts, cold }\end{array}$ \\
\hline & Habat hlawa & Pinpinella anisum & Seed & powder & Oral & Allergy \\
\hline & Maadnouss & \begin{tabular}{|l|} 
Petroose linum \\
sativum
\end{tabular} & $\begin{array}{l}\text { Aerial } \\
\text { part }\end{array}$ & Decoction & Oral & Respiratory \\
\hline & Camoun & \begin{tabular}{|l|}
$\begin{array}{l}\text { Cuminum } \\
\text { cyminum }\end{array}$ \\
\end{tabular} & Seed & tisane & Oral & Respiratory \\
\hline \multirow[b]{2}{*}{ Asphodelaceae } & Sebbar & Aloe socotrina 1 & Leaf & Tisane & Oral & Influenza \\
\hline & $\begin{array}{l}\text { Blalouz/ joudour } \\
\text { barwk }\end{array}$ & $\begin{array}{l}\text { Asphodelus } \\
\text { microcarpus }\end{array}$ & Rhizome & Powder & Goute & Asthma \\
\hline \multirow{4}{*}{ Asteraceae } & Taskra & Echinops spinosus & Stem & Decoction & Oral & cooling \\
\hline & $\begin{array}{l}\text { Buagad /hindiba } \\
\text { barri }\end{array}$ & Cichorium intybus & Leaf & Infusion & Oral & Respiratory \\
\hline & $\begin{array}{l}\text { Tarhella/oum } \\
\text { karman }\end{array}$ & Inula helenium & $\begin{array}{l}\text { Leaf, } \\
\text { flowers, } \\
\text { rhizome }\end{array}$ & Infusion & Oral & cough \\
\hline & Chih & $\begin{array}{l}\text { Artemisia herba- } \\
\text { alba asso }\end{array}$ & Leaf & Infusion & Oral & Respiratory \\
\hline Berberidaceae & Bosman & Berberis vulgaris & $\begin{array}{l}\text { Fruit, } \\
\text { stem bark }\end{array}$ & Decoction & Oral & $\begin{array}{l}\text { Bronchial } \\
\text { Inflammation }\end{array}$ \\
\hline
\end{tabular}




\begin{tabular}{|c|c|c|c|c|c|c|}
\hline Borraginaceae & Lessan laard & $\begin{array}{l}\text { Borrago } \\
\text { officinalis }\end{array}$ & $\begin{array}{l}\text { Leaf, } \\
\text { Seed }\end{array}$ & Infusion & Oral & \begin{tabular}{|l|} 
Cough, \\
Influenza
\end{tabular} \\
\hline \multirow{2}{*}{ Brassicaceae } & Hab rchad & Lipiduim sativum & Seed & Powder & Oral & $\begin{array}{l}\text { Tonsillitis, } \\
\text { Influenza }\end{array}$ \\
\hline & Fijl elhessan & $\begin{array}{l}\text { Armoracia } \\
\text { rusticana }\end{array}$ & Rhizome & crude & Oral & Influenza \\
\hline Cactaceae & Karmouss hindi & $\begin{array}{l}\text { Opuntia ficus } \\
\text { indica }\end{array}$ & Flowers & Infusion & Oral & Cooling \\
\hline Caprifoliaceae & Borwabez & \begin{tabular}{|l} 
Sambucus \\
canadensis
\end{tabular} & $\begin{array}{l}\text { Leaf, } \\
\text { Flowers }\end{array}$ & Infusion & Rinsing & $\begin{array}{l}\text { Bronchial } \\
\text { Inflammation }\end{array}$ \\
\hline Caryophyllaceae & Wijan/bilsan & Sambucus nigra & $\begin{array}{l}\text { Whole } \\
\text { plant }\end{array}$ & Decoction & Oral, Rinsing & Respiratory \\
\hline Champigions & Terfass & Terfezia leonis & Bulb & Decoction & Oral & Cooling \\
\hline Colchicaceae & \begin{tabular}{|l} 
Temrat \\
legrab/lessan \\
jmel
\end{tabular} & $\begin{array}{l}\text { Androcymbium } \\
\text { gramineum }\end{array}$ & Leaf & Infusion & Rinsing & $\begin{array}{l}\text { Bronchial } \\
\text { Inflammation }\end{array}$ \\
\hline Euphorbiaceae & Takaout & $\begin{array}{l}\text { Euphorbia } \\
\text { resinifera }\end{array}$ & Leaf & Powder & Oral & \begin{tabular}{|l} 
Asthma, \\
Influenza, \\
cough
\end{tabular} \\
\hline \multirow{2}{*}{ Fabaceae } & $\begin{array}{l}\text { Kharoub timarin } \\
\text { hindi }\end{array}$ & Ceratonia siliqua & Seed & juice & Oral & $\begin{array}{l}\text { Asthma, } \\
\text { cough }\end{array}$ \\
\hline & Arkssouss & $\begin{array}{l}\begin{array}{l}\text { Glycyrrhiza } \\
\text { glabra }\end{array} \\
\end{array}$ & Rhizome & Powder & Oral & cooling \\
\hline Gentianaceae & \begin{tabular}{|l|} 
Tamrat \\
alakrab/hchechat \\
laakreb
\end{tabular} & $\begin{array}{l}\text { Centaurium } \\
\text { spicatum }\end{array}$ & $\begin{array}{l}\text { Whole } \\
\text { plant }\end{array}$ & Decoction & Oral & $\begin{array}{l}\text { Inflammation } \\
\text { of respiratory } \\
\text { tract } \\
\end{array}$ \\
\hline Hydrangeaceae & Taililote/taylulut & Capparis spinosa & Seed & Cooked & Oral & Cooling \\
\hline Illiciaceae & Badyana & Illicium verum & Capsule & crude & Oral & Allergie \\
\hline Iridaceae & Zaafran & Crocus sativus & Stigma & Decoction & Oral & \begin{tabular}{|l|} 
Cooling, \\
Respiratory
\end{tabular} \\
\hline Juncaceae & Smar & Juncus maritimus & \begin{tabular}{|l}
$\begin{array}{l}\text { Seed, } \\
\text { rhizome }\end{array}$ \\
\end{tabular} & Powder & Oral & Asthma \\
\hline \multirow{6}{*}{ Lamiaceae } & Zaatar & \begin{tabular}{|l|} 
Origanun \\
glandulosum
\end{tabular} & Leaf & Infusion & Oral & $\begin{array}{l}\text { Influenza, } \\
\text { Cooling }\end{array}$ \\
\hline & $\begin{array}{l}\text { El } \\
\text { khouzama/halhal }\end{array}$ & $\begin{array}{l}\text { Lavandula } \\
\text { stoechas }\end{array}$ & Leaf & Infusion & Oral & \begin{tabular}{|l|} 
Cooling, \\
Influenza, \\
allergy, cough \\
\end{tabular} \\
\hline & Flio & Mentha pulegium & Leaf & Infusion & Oral & Cooling \\
\hline & Miriwt & $\begin{array}{l}\text { Marrubium } \\
\text { vulgrave }\end{array}$ & Leaf & Infusion & Oral & Cooling \\
\hline & Jaaidiya & $\begin{array}{l}\text { Teucrium } \\
\text { fruticans }\end{array}$ & $\begin{array}{l}\text { Aerial } \\
\text { part }\end{array}$ & Infusion & Oral & Influenza \\
\hline & Merdedouch & $\begin{array}{l}\text { Origanum } \\
\text { majorana }\end{array}$ & $\begin{array}{l}\text { Whole } \\
\text { plant }\end{array}$ & Infusion & Oral & Cooling \\
\hline Liliaceae & Korrat & Allium porrum & Bulb & Decoction & Oral & $\begin{array}{l}\text { Asthma in } \\
\text { children }\end{array}$ \\
\hline Malvaceae & Khebiza & Malva sylvestris & Leaf & Decoction & Oral & cough \\
\hline Moraceae & Karmouss & Ficus carica & Fruit & Decoction & Oral & Respiratory \\
\hline
\end{tabular}




\begin{tabular}{|c|c|c|c|c|c|c|}
\hline Myristicaceae & $\begin{array}{l}\text { Elgouza } \\
\text { sahraouiya }\end{array}$ & $\begin{array}{l}\text { Myristica } \\
\text { fragrans }\end{array}$ & Seed & Powder & Oral & Influenza \\
\hline \multirow{3}{*}{ Myrtaceae } & Caliptus & $\begin{array}{l}\text { Eucalyptus } \\
\text { globulus }\end{array}$ & Leaf & $\begin{array}{l}\text { Infusion, } \\
\text { Decoction }\end{array}$ & Oral, fumigation & $\begin{array}{l}\text { Influenza, } \\
\text { cooling }\end{array}$ \\
\hline & Krenfel & \begin{tabular}{|l}
$\begin{array}{l}\text { Eugenia } \\
\text { caryophyllata }\end{array}$ \\
\end{tabular} & Cloves & Infusion & Oral & \begin{tabular}{|l|} 
Antiseptic \\
Respiratory \\
\end{tabular} \\
\hline & Rayhan & Myrtus communis & Leaf & Infusion & Oral & $\begin{array}{l}\text { Cooling, } \\
\text { cough, } \\
\text { Influenza } \\
\end{array}$ \\
\hline Oleaceae & Zaytoun & Olea europaea & Huile & Tisane & Oral, massage & $\begin{array}{l}\begin{array}{l}\text { Influenza, } \\
\text { cough }\end{array} \\
\end{array}$ \\
\hline Papilionaceae & Lhalba & $\begin{array}{l}\text { Trigonella foenum } \\
\text { graecum }\end{array}$ & Seed & Crude, tisane & Oral & Respiratory \\
\hline Pinaceae & Tayda & Pinus halepensis & Leaf & Decoction & Oral & Respiratory \\
\hline \multirow[t]{2}{*}{ Plantaginaceae } & Massassa & Plantago major & Leaf & Juice & Oral & $\begin{array}{l}\text { Asthma, } \\
\text { tuberculosis }\end{array}$ \\
\hline & Zerktouna & Plantago psyllium & \begin{tabular}{|l|}
$\begin{array}{l}\text { Whole } \\
\text { plant }\end{array}$ \\
\end{tabular} & Infusion & Oral & Asthma \\
\hline Poaceae & Lakbal/draa & Zea mays & Oil & Oil & Oral, massage & Asthma \\
\hline Portulagaceae & Rejla & \begin{tabular}{|l} 
Portulaca \\
oleracea
\end{tabular} & $\begin{array}{l}\text { Aerial } \\
\text { part }\end{array}$ & Decoction & Oral & Cooling \\
\hline Ranunculaceae & $\begin{array}{l}\text { Saneuj/haba } \\
\text { sawda }\end{array}$ & Nigella sativa & Seed & Powder & Oral & \begin{tabular}{|l|} 
Cooling, \\
allergy, \\
respiratory
\end{tabular} \\
\hline \multirow{4}{*}{ Rutaceae } & Fijl ajmal & Ruta graveolens & $\begin{array}{l}\text { Leaf, } \\
\text { Flowers }\end{array}$ & Juice & Oral & $\begin{array}{l}\text { Inflammation } \\
\text { of respiratory } \\
\text { canals }\end{array}$ \\
\hline & Lemon & Citrus sinensis & Fruit & Infusion & Oral & \begin{tabular}{|l|}
$\begin{array}{l}\text { Influenza, } \\
\text { tonsillitis }\end{array}$ \\
\end{tabular} \\
\hline & Hamed & Citrus limon & Fruit & Juice & Oral & Respiratory \\
\hline & Zanboua & Citrus bigaradia & Fruit & Juice & Oral & Cough \\
\hline Valerianaceae & Sanbel & $\begin{array}{l}\text { Valeriana j } \\
\text { atamansi }\end{array}$ & Leaf & Powder & Oral & Asthma \\
\hline Verbinaceae & Louiza & $\begin{array}{l}\text { Verbena } \\
\text { officinalis }\end{array}$ & Leaf & Infusion & Oral & Respiratory \\
\hline Violaceae & Banafsaj & Viola tricolor & \begin{tabular}{|l|} 
Leaf, \\
Flowers \\
\end{tabular} & Infusion & Oral & Influenza \\
\hline \multirow{2}{*}{ Zingiberaceae } & Khedenjal & $\begin{array}{l}\text { Alpina } \\
\text { officinarum }\end{array}$ & Rhizome & Infusion & Oral & Cooling \\
\hline & Skenjbir & $\begin{array}{l}\text { Zingiber } \\
\text { officinale }\end{array}$ & Rhizome & Infusion & Oral & \begin{tabular}{|l} 
Cough, \\
Influenza
\end{tabular} \\
\hline
\end{tabular}




\section{REFERENCES}

[1] El MeskaouiA., Bousta D., Dahchour A., Greche H., Harki A., Farah A., \& Ennabili A., 2008. Plantes médicinales et aromatiques marocaines : opportunités et défis, Revue AFN Maroc.

[2] Bellakhdar J., 2006. Plantes médicinales au Maghreb et soins de base. Précis de phytothérapie moderne. Editions Le Fennec, Casablanca.

[3] Bellakhdar J., 1997: La pharmacopée marocaine traditionnelle médecine arabe ancienne et savoirs populaires.

[4] Benkhnigue O., Zidane L., Fadli M., Elyacoub.H., Rochdi A., \& Douira. A., 2010-2011. Etude ethnobotanique des plantes médicinales dans la région de Mechraâ Bel Ksiri (Région du Gharb du Maroc). Acta Bot. Barc. 53: 191-216 Barcelona, 2010-2011.

[5] El Hilah F., Ben Akka F., Dahmani J., Belahbib N., Zidane L., Étude ethnobotanique des plantes médicinales utilisées dans le traitement des infections du système respiratoire dans le plateau central marocain, Journal of Animal \& Plant Sciences, 2015. Vol.25

[6] Fennane et al. 1999, 2007. Flore pratique du Maroc, Volume 1 et 2 .

[7] Fennane et Ibn Tattou. 2005. Flore vasculaire du Maroc : inventaire et chorologie (volume 1).

[8] Hmamouchi M., 1999. Les plantes médicinales et aromatiques marocaines, utilisation, biologie, écologie, chimie, pharmacologie, toxicologie, lexiques. 387 p.

[9] Hmamouchi M., 2001. Les plantes médicinales et aromatiques marocaines, 2ème édition;

[10] Ministère de la Santé, Direction de l'Epidémiologie et de Lutte Contre les Maladies. 2001. Prise en charge combinée des maladies respiratoires et de la tuberculose au Maroc.

[11] Monographie générale de la région Béni mellalKhénifra. 2015

[12] Hseini S., Kahouadji A., Lahsissène H. \& Tijane M., 2011. Analyses floristique et ethnobotanique des plantes vasculaires médicinales utilisées dans la région de Rabat (Maroc occidental) — Lazaroa, 28, pp. 93-100.

[13] Mehdioui R., Kahouadji A., 2007. Etude ethnobotanique auprès de la population riveraine de la forêt d'Amsittène : cas de la Commune d'Imin'Tlit (Province d'Essaouira).Bulletin de l'institut scientifique, rabat, section science de la vie, $29,11-20$.
[14]Quézel \& Santana 1962-1963. Nouvelle flore d'Algérie et des régions désertiques méridionales, tomes I et II.

[15] Sijelmassi A., 1993. Les plantes médicinales du Maroc, 6ème édition. Le Fennec, Casablanca. 285p.

[16].Valdés et al 2002. Catalogues des plantes vasculaires du Nord du Maroc, incluant des clés d'identification, de volumes I et II.

[17] Vines G., 2004. Herbal harvests with a future: towards sustainable sources for medicinal plants, Plant life International; www.plantlife.org.uk 